\title{
Images in Practice: Painful Cutaneous Vasculitis in a SARS-Cov-2 IgG-Positive Child
}

\author{
Alfonso Papa (D) - Anna M. Salzano - M. Teresa Di Dato · \\ Giustino Varrassi
}

Received: May 6, 2020 / Published online: May 21, 2020

(C) The Author(s) 2020

Keywords: Child; Coronavirus; COVID-19; Vasculitis

\section{INTRODUCTION}

The spread of severe acute respiratory syndrome coronavirus-2 (SARS-CoV-2) during the ongoing coronavirus disease 2019 (COVID-19) pandemic has been particularly high in Italy. In Italy, as in the rest of the world, extremely rare cases of infection have been seen in the pediatric population. In a study carried out in China involving more than 44,000 cases of COVID-19, $0.9 \%$ of patients were between 0 and 10 years of age and $1.2 \%$ ranged in age from 10 to 19 years [1]. The absence of evident symptoms in children has reduced the need for nasopharyngeal and oropharyngeal swab screening in this age group [2], with the result that little information is currently available on this segment of the population. During the pandemic period in Italy, we observed more than ten pediatric

Digital Features To view digital features for this article go to https://doi.org/10.6084/m9.figshare.12295805.

A. Papa $(\varangle)$ · A. M. Salzano · M. T. Di Dato

Pain Department, Monaldi Hospital, AO Ospedali dei Colli, Naples, Italy

e-mail: alfonsopapa@libero.it

G. Varrassi

Paolo Procacci Foundation, Via Tacito 7, 00193

Rome, Italy patients who tested IgG positive for Sars-CoV-2 with painful vasculitic skin lesions on the feet that required modest pain relief therapy. Here, we describe the case history of one of these patients and present pictures of her condition.

\section{CASE: 11-YEAR-OLD GIRL}

At the first observation, the patient had erythematous chilblain-like skin lesions on her feet and several ulcerative lesions with dyschromia of the nails (Fig. 1a); the erythematous areas did not disappear with finger pressure. In the previous 6 weeks she had not shown fever, cough, malaise or asthenia. Her medical history was negative for vascular and/or inflammatory conditions. She reported mild to moderate pain and itching. All blood tests were negative (complete blood count, ESR, PCR analysis, D-dimer, creatinine, AST, ALT, C3, C4, IL-6 and 25 -hydroxyvitamin D). No Sars-CoV-2 virus was detected on the nose and oropharyngeal swab, while serologic testing for Sars-CoV-2 antibodies revealed Sars-CoV-2 IgG at $5.2 \mathrm{AU} / \mathrm{ml}$ (normal range $>1 \mathrm{AU} / \mathrm{ml}$ ) and Sars-CoV-2 $\mathrm{IgM}$ at $0.8 \mathrm{AU} / \mathrm{ml}$ (normal range $>1 \mathrm{AU} / \mathrm{ml}$ ).

The pain measured using the Oucher scale, with the results indicating a score of 2 (range $0-5$ ).

The patients was immediately treated with paracetamol $750 \mathrm{mg} 4$ times/day. Some of these lesions became purulent in the following days 

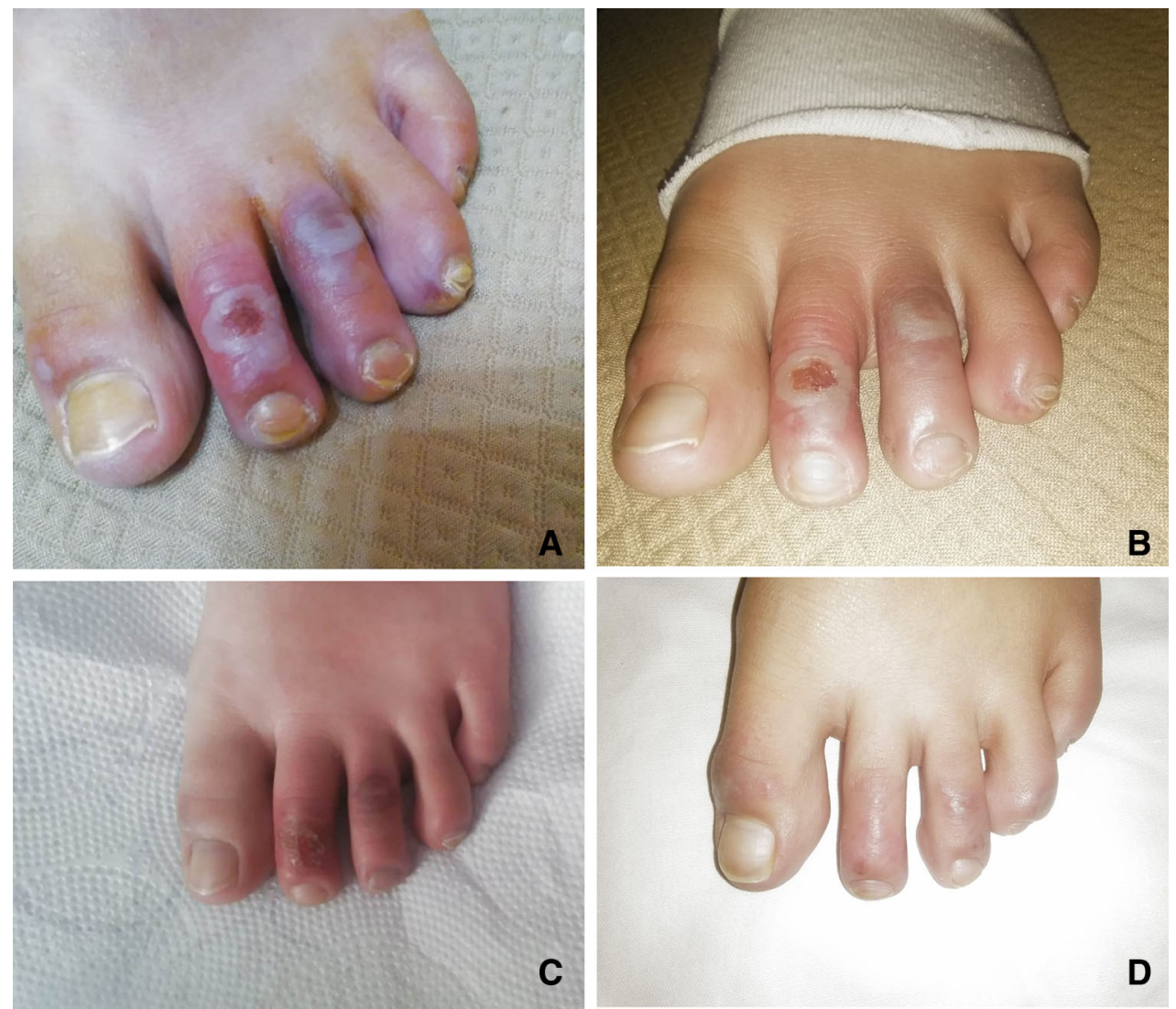

Fig. 1 Vasculitic skin lesions on the feet of an 11-year-old girl. a Painful skin lesions at first observation, b skins lesion after 7 days, $\mathbf{c}$ skin lesions after 10 days, $\mathbf{d}$ complete resolution of skin lesions after 15 days of treatment

and was treated with Mupirocin 2\% Ointment 3 time per day.

After 7 days the analgesic therapy was discontinued (Fig. 1b, c), and after 15 days the skin lesions were completely resolved (Fig. 1d).

\section{CONCLUSION}

The lack of finger pressure clearing of the eritematous lesions suggests that the vasculitis in our patient was of an ischemic hemorrhagic nature. In the pediatric population there are numerous clinical conditions of a predominantly infectious or immune-mediated origin that can be associated with hemorrhagic ischemic vasculitis. One of the most of these, Kawasaki disease, has already been correlated with COVID-19 [3]. Although it is not possible to correlate our patient case with the presence of SARS-COV-2 due to the swab negativity, we believe that the positive result for SARS-COV-2 IgG antibodies does correlate the skin lesion with COVID-19. This belief is reinforced by the fact that similar vasculitic manifestations associated with coagulation disorders, cyanosis and gangrene have been reported as late manifestations in severe COVID-19 cases in adults [4-6].

\section{ACKNOWLEDGEMENTS}

We thank the patient and her family for their willingness to share this case and the pictures. 
Funding. No funding or sponsorship was received for this study or publication of this article.

Authorship. All named authors meet the International Committee of Medical Journal Editors (ICMJE) criteria for authorship for this article, take responsibility for the integrity of the work as a whole, and have given their approval for this version to be published.

Disclosures. Alfonso Papa, Anna Maria Salzano and Maria Teresa Di Dato have nothing to disclose. Giustino Varrassi is a member of the journal's Editorial Board.

Compliance with Ethics Guidelines. Informed consent for publication was obtained from the patient's parents.

Data Availability. The datasets during and/ or analyzed during the current study are available from the corresponding author on reasonable request.

Open Access. This article is licensed under a Creative Commons Attribution-NonCommercial 4.0 International License, which permits any non-commercial use, sharing, adaptation, distribution and reproduction in any medium or format, as long as you give appropriate credit to the original author(s) and the source, provide a link to the Creative Commons licence, and indicate if changes were made. The images or other third party material in this article are included in the article's Creative Commons licence, unless indicated otherwise in a credit line to the material. If material is not included in the article's Creative Commons licence and your intended use is not permitted by statutory regulation or exceeds the permitted use, you will need to obtain permission directly from the copyright holder. To view a copy of this licence, visit http://creativecommons.org/licenses/by$\mathrm{nc} / 4.0 /$.

\section{REFERENCES}

1. Novel Coronavirus Pneumonia Emergency Response Epidemiology Team. The epidemiological characteristics of an outbreak of 2019 novel coronavirus diseases (COVID-19) in China. Zhonghua Liu Xing Bing Xue Za Zhi. 2020;41(2):145-51.

2. Qiu H, Wu J, Hong L, Luo Y, Song Q, Chen D. Clinical and epidemiological features of 36 children with coronavirus disease 2019 (COVID-19) in Zhejiang, China: an observational cohort study. Lancet Infect Dis. 2020. https://doi.org/10.1016/S14733099(20)30198-5.

3. Jones VG, Mills M, Suarez D, et al. COVID-19 and Kawasaki disease: novel virus and novel case. Hosp Pediatr. 2020. https://doi.org/10.1542/hpeds.20200123.

4. Recalcati S. Cutaneous manifestations in COVID-19: a first perspective. J Eur Acad Dermatol Venereol. 2020. https://doi.org/10.1111/jdv.16387.

5. Zhang Y, Cao W, Xiao M, et al. Clinical and coagulation characteristics of 7 patients with critical COVID-2019 pneumonia and acro-ischemia. Zhonghua Xue Ye Xue Za Zhi. 2020;41:E006. https://doi. org/10.3760/cma.j.issn.0253-2727.2020.0006.

6. Pergolizzi JV Jr, Magnusson P, LeQuang JA, et al. The current clinically relevant findings on COVID-19 pandemic. Anesth Pain Med. 2020;10(2):e819. https://doi.org/10.5812/aapm.103819. 